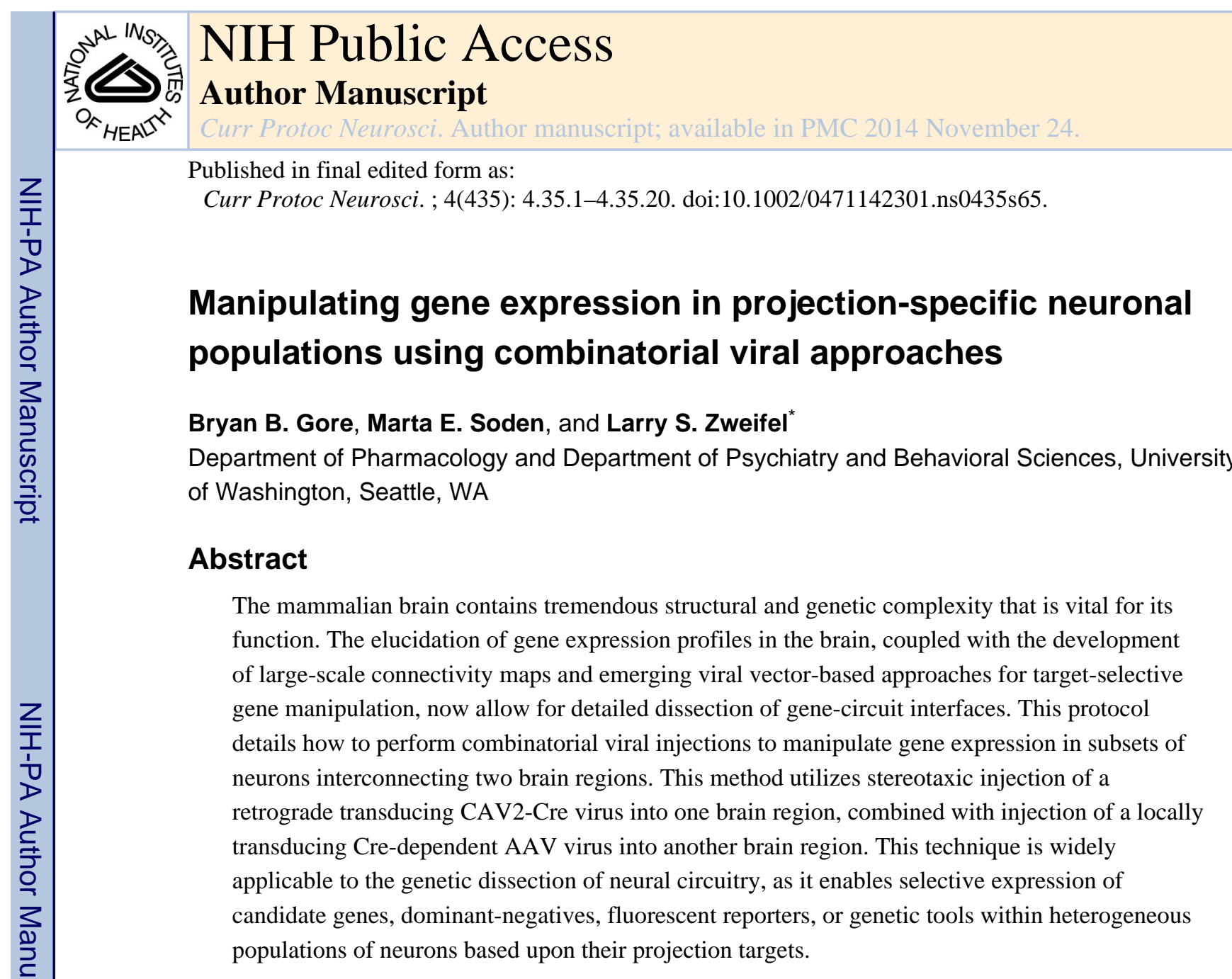

Keywords

AAV; CAV; viral vector; neural circuit; stereotaxic surgery

\title{
INTRODUCTION
}

The human brain contains an estimated 100 billion neurons that collectively generate trillions of synaptic connections (Hubel, 1979; Lent et al., 2012). In tandem to this structural complexity, the human genome contains over 20,000 protein-encoding genes (Consortium, 2004), many with heterogeneous expression patterns in the brain (Hawrylycz et al., 2012). Merging these two independently complex landscapes to map the genetic influence on brain connectivity and function represents one of the greatest challenges for modern neuroscience. Studies of genetic model organisms such as zebrafish (Danio rerio), fruit flies (Drosophila melanogaster), and nematodes (Caenorhabditis elegans) have significantly advanced our

\footnotetext{
*To whom correspondence should be addressed: Larry S. Zweifel, 1959 NE Pacific St., Box 357280, Seattle, WA 98195; larryz@u.washington.edu.

INTERNET RESOURCES

Jackson Labs http://jaxmice.jax.org/

GENSAT http://www.gensat.org

Allen Institute for Brain Science http://www.brain-map.org/

AIBS Connectivity Atlas: http://connectivity.brain-map.org/
} 
understanding of how genes control the evolutionarily conserved processes of neurogenesis, neural fate specification, axon guidance, synaptogenesis, and neuronal survival (Hadjieconomou et al., 2011; Luo et al., 2008; Robles and Baier, 2012; Wang and Jin, 2011). To better understand the intersection between genes and neural circuits at the systems level in the mammalian nervous system, the house mouse (Mus musculus) has emerged as an unparalleled model organism based on the tractability of genetic manipulation.

The genetic toolbox available to interrogate circuit function in mice has expanded exponentially over the past two decades (Luo et al., 2008). The possibility of functionally testing a gene of interest in a select brain region is now a reality in modern neuroscience. In this protocol, we will outline the essential steps to manipulate gene expression in a targetselective manner. The focus will be on using combinatorial viral approaches to fluorescently label, functionally alter, or genetically perturb specific projections connecting two brain regions.

The use of viral vectors in neurobiological research has expanded due to their increasing flexibility and the ability to deliver viral particles to precise brain regions. Use of adenoassociated virus (AAV) in particular has become widespread due to its ease of production, low tropism, stable expression, and non-toxic nature (Scammell et al., 2003; Slack and Miller, 1996). AAV viral vectors in which transgene expression is dependent on Cre recombinase are widely available, allowing for conditional, cell-selective gene expression (Schnutgen et al., 2003). When Cre-dependent AAV viral vectors are injected into a mouse brain expressing $\mathrm{Cre}$ in a discrete subset of neurons (a Cre driver mouse line), then Cremediated recombination of the transgene will facilitate expression of the viral constructs in a restricted manner.

Current Cre driver mouse lines allow for regionally restricted and cell-type specific manipulation of gene expression; however, they are often insufficient to isolate projectionspecific neuronal populations. To precisely define genetic control over circuit function development of methodologies allowing for specific transgene expression in subset of neurons based strictly upon their projection targets is critical. This protocol outlines a method that combines the use of locally transducing Cre-dependent AAV viruses with the retrograde transducing Canine Adenovirus 2 expressing Cre (CAV2-Cre). CAV2 is a desirable means of retrograde $\mathrm{Cre}$ delivery, as $\mathrm{CAV}$ viral vectors are largely restricted to transduction of neurons, permit stable expression, and have little to no toxicity (Hnasko et al., 2006; Kremer et al., 2000; Soudais et al., 2001). Dual viral injections of AAV and CAV2-Cre into interconnected regions will selectively label the subset of neurons projecting from one region to another. A wide array of constructs can be cloned into an AAV vector, enabling the conditional expression of candidate genes, dominant negatives, fluorescent reporters (calcium, $\mathrm{pH}$, or voltage sensors), and optogenetic or pharmacogenetic tools.

The Basic Protocol outlined below provides a general template for planning and executing a combinatorial virus experiment, which can be adapted to address a wide range of experimental hypotheses. Detailed instructions on virus production, stereotaxic surgery, and post-hoc sectioning of brain tissue are provided in the support protocols. 
Importantly, though this protocol describes experiments performed on mice, many of the experiments described are equally suited for use in rats (Witten et al., 2011). It should also be noted that although we exclusively describe the use of AAV1/2 and CAV2 here, in principle other combinations of local and retrograde viral vectors can be used, including lentivirus (Ahmed et al., 2004), herpes-simplex virus (Lo and Anderson, 2011), pseudorabies virus (Card et al., 2011), or rabies virus (Osakada et al., 2011).

\section{BASIC PROTOCOL}

\section{Using combinatorial viral strategies to study gene-circuit interfaces}

Studies using electrolytic, physical, and chemical lesions have identified critical functions for many different brain regions. In addition, knockout animals and pharmacological agonists and antagonists with varying degrees of specificity have been used to probe gene and protein function. These methods typically fail to discriminate between neurons with heterogeneous projections to multiple targets. For example, midbrain dopamine neurons, once thought to be a homogeneous population of neurons, have been demonstrated to be quite diverse, projecting to a diversity of downstream targets (Lammel et al., 2013).

Therefore, it is advantageous to functionally test for genetic requirements in neurons based upon their projection specificity. As detailed below, this can be achieved by performing dual viral injections in two brain regions.

Before beginning this protocol, a researcher must determine which brain regions express a gene of interest and establish the connectivity of those regions. Many resources are available to help researchers identify such connections. In addition to data in the primary literature from specific mapping studies, a large scale "connectomics" project is currently underway at the Allen Institute for Brain Science (AIBS). This project aims to systematically map all the interconnections in the mouse brain. Their online resource (http://connectivity.brainmap.org/) provides a valuable starting point for identifying intriguing circuit connections, but once a potential projection is identified this data should be confirmed and expanded upon by the researcher, as outlined here:

\section{Materials}

Mouse brain atlas

Fluorogold (available from Fluorochrome, LLC)

Wild-type mouse, fluorescent reporter mouse, or Cre driver mouse

Adeno-associated virus encoding reporter or gene of interest (AAV; see support protocol 2)

Canine associated virus-2 encoding Cre recombinase (CAV2-Cre; see support protocol 3)

Establish coordinates for injections: After identifying the brain regions to be studied, coordinates for stereotaxic injections must be optimized as follows: 
1 Determine initial coordinates (anterior-posterior, dorsal-ventral, and mediallateral) by locating the injection target in a brain atlas. There are several high quality mouse brain atlases available, including the widely-used print atlas by Paxinos and Franklin (Paxinos and Franklin, 2013) or the atlas generated by the AIBS, available both in print (Dong, 2008) and free online (http://www.brainmap.org/).

2 During stereotaxic surgery (see support protocol 1), inject $0.2 \mu$ l of Fluorogold or another appropriate dye at the determined coordinates. As injection accuracy can vary, it is suggested that 2-4 animals are injected using the same coordinates.

3 Perfuse the animal 24 hours following the injection, according to approved procedures. Though Fluorogold will eventually be transported retrogradely and spread to neurons throughout the brain (see below), cells surrounding the injection site will be strongly labeled and easily identifiable at this time point.

4 Section brain tissue (see support protocol 4), collecting sections surrounding the region of injection. Note that stereotaxic injection does not always lead to a spherical diffusion. For example, white matter tracts in the brain can act as barriers to alter the diffusion pattern, so it is important to sample across a large region (+/- $1 \mathrm{~mm}$ from the injection site) to reveal the complete diffusion pattern.

5 If the location of the injection does not match the intended coordinates, adjust the coordinates accordingly and repeat with additional animals until consistent, accurate injections are achieved.

6 Once coordinates are determined, perform test injections using viral vectors, adjusting titer and injection volume to cover the desired region. A good starting point is $0.5 \mu \mathrm{l}$ of virus at a titer of $1 \times 10^{9}$ particles/ $\mu$ l. Allow a longer time between injection and perfusion (10-14 days) to ensure full expression of the virus.

\section{Identify circuit connections}

$7 \quad$ Perform anterograde tracing studies: An anterograde tracing study will determine the projection targets of a specific brain region. Three alternate methods are presented here. All methods utilize stereotaxic injection, described in support protocol 1, AAV virus production, described in support protocol 2, and tissue sectioning, described in support protocol 4.

A. Stereotaxic injection of a non-conditional AAV encoding a fluorescent protein. When stereotaxically injected into a region of interest, an AAV encoding a fluorescent marker (i.e. GFP) will transduce neurons surrounding the injection site. The cell bodies and processes of these neurons will be filled with the fluorescent protein, allowing for visualization of projection targets. After stereotaxic injection (see support protocol 1), allow approximately 2 weeks for full expression. 
Perfuse the animal and section the brain tissue (see support protocol 4); projection targets of the region of interest will contain fluorescently labeled fibers. Specificity can be increased by reducing the injection volume and/or virus titer to limit the number of cells transduced by the virus.

B. Stereotaxic injection of AAV-Cre into a genetic fluorescent reporter mouse. Several mouse lines are available containing a "floxed-stop" fluorescent reporter, such as GFP or TdTomato at the Rosa26 genome locus (Madisen et al., 2010). In these animals, reporter expression occurs only in the presence of Cre recombinase. Stereotaxic injection of AAV-Cre into a region of interest will turn on the reporter in the neurons of that region, allowing for visualization of processes following brain tissue sectioning, as described above. We recommend the Rosa26-fs-TdTomato line (Gt(Rosa)26Sor<tm14, or Ai14), available from Jackson Laboratories) because of its high fluorescence intensity (Madisen et al., 2010).

C. Stereotaxic injection of a conditional AAV into a specific Cre driver line. In order to identify the projection targets of a specific population of neurons, a mouse line expressing Cre recombinase under a cell-type specific promoter can be used (see section on Internet Resources). If such a line is available, stereotaxic injection of a conditional AAV vector will result in reporter expression only in Cre-expressing neurons near the injection site. One configuration for conditional expression that has proved successful is the double-floxed inverted open reading frame, termed DIO or FLEX (Schnutgen et al., 2003). Projection fibers containing the fluorescent reporter can be visualized as described above.

Perform retrograde tracing study: Unlike the anterograde tracing study underway at the AIBS, no large-scale map of retrograde connections is available. Two potential methods are suggested for simple labeling of neurons that project to a given target. CAV2 production is described in support protocol 3.

A. CAV2-Cre injection in a reporter mouse line (recommended method): Stereotaxically inject CAV2-Cre into a fluorescent reporter mouse line, such as Ai14 (Madisen et al., 2010). CAV2-Cre will be taken up by synaptic terminals at the injection site and will be retrogradely transported to cell bodies, turning on reporter expression in those cells. Projection inputs can be identified by sectioning of the brain tissue and screening for fluorescently labeled cell bodies.

B. Fluorogold injection in a wild-type mouse: Fluorogold is a retrogradely transported dye that will label neurons projecting to the site of injection. Stereotaxically inject $0.2 \mu \mathrm{l}$ of $4 \%$ Fluorogold in saline into the target region. Perfuse animals 7-10 days following injection and 
section the brain tissue. Following sectioning, Fluorogold can be visualized under UV illumination.

\section{Perform dual viral injections}

9 Once accurate coordinates and injection parameters have been verified, dual injection surgeries can be performed on a cohort of animals intended for behavioral or electrophysiological studies (allow 2-3 weeks following surgery for recovery and full viral expression before experiments are performed). Three classes of experiments are presented here, each of which alters gene expression in neurons projecting from one specific brain region to another. All three rely on injection of CAV2-Cre into the projection target region, but each utilizes a different Cre-dependent AAV injected into the projection origin region. Each experiment should include appropriate controls, typically animals expressing a control virus such as GFP.

A. Expression of an artificial regulator of cellular activity: Light activated ion channels and pumps, such as channelrhodopsin, halorhodopsin, and archaerhodopsin (Fenno et al., 2011), can be used to induce or inhibit action potential firing in neurons in vivo or in vitro. Receptors Activated Solely by Selective Ligands (RASSLs) (Coward et al., 1998) and Designer Receptors Exclusively Activated by Designer Drugs (DREADDs) (Armbruster et al., 2007) are ligand-activated receptors that can also be used to activate or inhibit cellular activity in vivo or in vitro by administration of a specific agonist. Such artificial regulators of neural activity can be used to probe the consequences of increasing or decreasing activity within a given circuit element.

B. Loss-of-function through expression of a conditional dominantnegative or gain-of-function through conditional gene overexpression: Considerable insight into gene function can be gained through conditional, projection-specific expression of a dominant-negative to reduce protein function, or through conditional gain-of-function through gene overexpression.

C. Rescue of gene knockout by re-expression: Minimal gene sufficiency can be tested in select neural projections utilizing conventional knockout mice together with a combinatorial virus approach. Starting with a null genetic background, a conditional AAV encoding the gene to be rescued is injected into a brain region of interest and CAV2-Cre is injected into a projection target, allowing for selective reconstruction of gene sufficiency within a circuit (Parker et al., 2011).

\section{Post-hoc histology}

10 Following behavioral or other experimentation, all animals should be perfused and histology should be performed in order to confirm targeting (see support protocol 4). Criteria should be established (i.e. a certain number or percentage of 
cells transduced) in order to enable an unbiased determination of whether targeting was sufficiently accurate to include a given animal in behavioral analysis.

\section{SUPPORT PROTOCOL 1}

\section{Stereotaxic surgery for viral delivery to brain}

This support protocol details how to stereotaxically inject virus, fluorescent tracer, or dye to a brain region of interest. This technique can be applied to single or multiple injections.

\section{Materials}

Wild-type mouse, fluorescent reporter mouse, or Cre driver mouse

Sterile cotton swabs

Sterile water

Sterile $0.9 \%$ saline

Topical anesthetic

Betadine

Sutures or surgical adhesive

Desired virus, dye, or tracer

Stereotaxic equipment (e.g. from Kopf):

Stereotaxic Alignment Instrument

Centering Scope 40x

Stereotaxic Alignment Indicator

Stereotaxic Drill

Syringe Holder

Electric razor

Microsyringe pump (e.g. from World Precision Instruments)

$5 \mu$ injection syringe (e.g. from Hamilton)

Surgical tools:

Forceps

Scalpel

Skin Clamps

Protocol steps: All surgical procedures should be performed only in accordance with a protocol approved by your Institutional Animal Care Use Committee, which might require different methods for anesthesia, surgical procedures, pain management, and post-surgical care and follow-up. Make sure all surgical equipment is sterilized prior to use.

Curr Protoc Neurosci. Author manuscript; available in PMC 2014 November 24. 
1. Under anesthesia (typically induced by isofluorane), place front teeth of mouse in bite bar in the stereotaxic frame and secure the skull in place using the earbars, ensuring the tick marks on each earbar are equal. Skull should not shift under moderate pressure.

2. Remove hair from top of the head using an electric razor.

3. Apply topical anesthetic with a cotton swab; after 5 minutes remove with a clean swab and rinse skin with sterile water.

4. Apply Betadine sterilizing solution with a cotton swab; rinse with sterile water and repeat 2 more times.

5. Using a scalpel, cut the skin on the top of the head down the midline and expose the skull. Use skin clamps to keep skin flaps pulled apart.

6. Using the microscope attachment, locate bregma and adjust the stereotaxic apparatus to center bregma underneath the crosshairs of the microscope. Zero the values of the $\mathrm{x}, \mathrm{y}$, and $\mathrm{z}$ arms of the stereotaxic device.

7. Use the stereotaxic device to measure the distance between bregma and lambda (Figure 1). Move halfway between bregma and lambda, and use the alignment indicator attachment to level the skull in the left-right and anterior-posterior directions.

8. Return the stereotaxic frame to the zero position and confirm bregma is still centered under the microscope. Adjust if necessary.

9. Re-measure the distance between lambda and bregma.

10. Adjust the anterior-posterior (A-P) coordinate based on the lambda to bregma distance. The "standard" mouse has a lambda-bregma distance of $4.21 \mathrm{~mm}$; therefore, calculate an adjustment factor $(\mathrm{F})$ by dividing the measured lambdabregma distance (in $\mathrm{mm}$ ) by 4.21 (Figure 2). Multiply F by the chosen A-P coordinate to calculate the adjusted value. There is no need to adjust the mediallateral or dorsal-ventral coordinates.

11. Drill holes at the appropriate coordinates, taking care not to lower the drill into the brain tissue. Apply pressure with a cotton swab to control any minor bleeding.

12. Load a syringe with the first virus or tracer, and place the syringe in the syringe holder on the stereotaxic arm.

13. Touch the tip of the syringe to bregma, and zero the $\mathrm{z}$ coordinate.

14. Expel a small amount of liquid from the syringe to verify that no air bubbles are present.

15. If necessary, clear drilled holes of dried blood using sterile saline and a cotton swab. Slowly lower the syringe through the drilled hole to a distance $0.5 \mathrm{~mm}$ deeper than the dorsal-ventral injection coordinate and wait two minutes. 
16. Begin the injection. The syringe pump should be set to a rate of $250 \mathrm{nl} / \mathrm{min}$. Total volume injected should be determined empirically, but is typically 250-750 nl. While the syringe is injecting, slowly raise the syringe $0.5 \mathrm{~mm}$.

17. Wait an additional 10 minutes, then slowly remove the syringe.

18. Expel a small amount of liquid from the syringe to clear blood and/or cerebrospinal fluid from the tip.

19. Repeat steps $13-18$ for additional injections. If possible, use a separate syringe for each virus. If a single syringe is to be used with more than one virus, rinse thoroughly with sterile water in between injections.

20. Close the incision using sutures or medical adhesive and perform post-surgical follow-up care as indicated by your IUCAC protocol.

\section{SUPPORT PROTOCOL 2}

\section{Adeno-associated virus production}

Adeno-associated virus (AAV) has become widespread in neurobiological studies due to its ease of use, stable expression, and low tropism (Scammell et al., 2003). Production of AAV requires a shuttle vector containing your construct of interest and a packaging vector encoding additional components necessary for virus production (Gregorevic et al., 2004). Many shuttle vectors already contain the sequences required for Cre-dependent gene expression (Schnutgen et al., 2003). The primary limitation of AAV is its small capacity. The typical size limitation for a cDNA to be cloned into a conditional AAV shuttle vector is approximately $2.3 \mathrm{~Kb}$ (assuming a promoter of approximately $1 \mathrm{~Kb}$, such as the CAG promoter (Judge and Chamberlain, 2005).

Note: The packaging vector is time-consuming and labor-intensive to produce. We recommend outsourcing the amplification and purification of the packaging vector to a plasmid manufacturing company, such as Nature Technology.

\section{Materials}

HEK293T/17 cells, low passage

HEK culture media (see recipe)

$10 \mathrm{~cm}$ tissue culture dishes

$15 \mathrm{~cm}$ tissue culture dishes

$0.25 \%$ Trypsin-EDTA

$50 \mathrm{ml}$ conical tubes

AAV shuttle vector with desired construct

pDG-1 packaging vector

$2 \mathrm{M} \mathrm{CaCl}_{2}$, sterile

$2 \times$ HEPES solution (see recipe) 
Phosphate mix (see recipe)

Pasteur pipette

Serum-free HEK media (see recipe)

Dry ice

$95 \%$ ethanol

$25 \times 89 \mathrm{~mm}$ large ultracentrifuge tubes (e.g. from Beckman)

$40 \%$ sucrose in $\mathrm{PBS}$, sterile

$\mathrm{CsCl}$ solution (see recipes)

$13 \times 51 \mathrm{~mm}$ heat-seal ultracentrifuge tubes (e.g. from Beckman)

$1.5 \mathrm{ml}$ tubes

6× DNA loading buffer/dye

$1 \%$ agarose gel

Ethidium bromide or equivalent

$1 \times$ HBSS (Hanks’ Balanced Salt Solution)

10,000 molecular weight cutoff dialysis cassettes, $0.5-3 \mathrm{ml}$ capacity (e.g. from Pierce)

$5 \mathrm{ml}$ syringe and 20 gauge needle

$0.2 \mu \mathrm{m}$ pore syringe filter

Parafilm

Incubator for cell culture $\left(37^{\circ} \mathrm{C}, 5 \% \mathrm{CO}_{2}\right)$

Biosafety cabinet

Water bath $\left(37^{\circ} \mathrm{C}\right)$

Hemocytometer

Clinical centrifuge

Sealer for heat-seal tubes

Ultracentrifuge

SW-27 rotor (or equivalent)

VTi-65 rotor (or equivalent)

Electrophoresis equipment for agarose gel

UV box

Preparation of HEK293T/17 cells ( 1 week prior to Day 1): All steps should be performed in a tissue culture hood until cells have been harvested.

Curr Protoc Neurosci. Author manuscript; available in PMC 2014 November 24. 
1 Thaw frozen cell stock $\left(\sim 5 \times 10^{6}\right.$ cells $)$ in a $37^{\circ} \mathrm{C}$ water bath for approximately 5 minutes. Add to a $10 \mathrm{~cm}$ culture dish along with $10 \mathrm{ml}$ warm HEK culture media, rock gently to disperse and place in incubator.

2 The next day, aspirate media from plate and immediately add $5 \mathrm{ml}$ warm Trypsin-EDTA. Incubate 2 minutes at $37^{\circ} \mathrm{C}$.

3 Aspirate Trypsin-EDTA and immediately add $10 \mathrm{ml}$ of warm culture media to the plate. Triturate cells until dispersed and transfer to a $15 \mathrm{~cm}$ culture dish with an additional $10 \mathrm{ml}$ of culture media $(20 \mathrm{ml}$ total).

4 Grow cells in incubator 2-4 days until confluent. Prepare five $15 \mathrm{~cm}$ dishes with $20 \mathrm{ml}$ of warm culture media. Use EDTA-Trypsin (as described in steps 2-3) to resuspend cells, and divide cells evenly among the $15 \mathrm{~cm}$ dishes. Rock gently to disperse and return to incubator. Cells should be confluent in $2-4$ days.

\section{Day 1}

$5 \quad$ Resuspend cells (as described in steps 2-3) and count density using a hemocytometer. Plate cells at a density of $\sim 3.7 \times 10^{6}$ cells $/ 10 \mathrm{~cm}$ dish in $10 \mathrm{ml}$ HEK culture media. The steps below assume a total of fifty $10 \mathrm{~cm}$ dishes, but this number can be adjusted depending on desired yield.

\section{Day 2: Transfection}

6 Transfect in the early afternoon. For each $10 \mathrm{~cm}$ plate, mix together in a $50 \mathrm{ml}$ conical tube:

$50 \mu \mathrm{l} 2 \mathrm{M} \mathrm{CaCl}_{2}$

$10 \mu \mathrm{g}$ AAV vector

$20 \mu \mathrm{g}$ pDG1 shuttle vector

$\mathrm{ddH}_{2} \mathrm{O}$ to $400 \mu \mathrm{l}$

7 In a separate tube, for each $10 \mathrm{~cm}$ plate mix together:

$396 \mu \mathrm{l} 2 \times$ HEPES solution

$4 \mu$ l phosphate mix

NOTE: Test transfections should be performed prior to beginning the protocol to determine optimal amount of phosphate mix for peak transfection efficiency. Up to $8 \mu \mathrm{l} /$ plate may be required.

8 Add DNA solution dropwise to phosphate solution while gently vortexing. Solution should be cloudy with fine particles (no large clumps).

9 Incubate precipitation for 10-15 minutes at room temperature. Vortex on high briefly to break up any large particles, then add $800 \mu$ gently to each plate of cells. Be careful to avoid dislodging cells. Gently rock plate to spread the precipitation. Fine particles should be visible under the microscope. Return cells to incubator. 


\section{Day 3}

10 First thing in the morning, use a vacuum with sterile Pasteur pipette to remove the media from each plate and replace with $10 \mathrm{ml}$ warm serum-free HEK media. Take care to avoid dislodging cells.

11 Incubate for 48 additional hours.

\section{Day 5: Harvest and purify viral vector}

12 Cells should look round but still attached; culture media may be yellow. Using a pipette-aid to dislodge cells with repeated pipetting, harvest cells from all plates in a total of $120 \mathrm{ml}$ media. Divide the harvested cells and media evenly into 450 $\mathrm{ml}$ conical tubes.

13 Liberate viral vector through repeated freeze-thaw cycles. Freeze tube completely in a bath of dry ice and ethanol; solution may turn from red to yellow/orange. Place tube into $37^{\circ} \mathrm{C}$ water bath and thaw completely. Repeat for a total of 3-freeze/thaw cycles.

14 Spin tubes in a clinical centrifuge at $2000 \mathrm{rpm}$ for 30 minutes.

15 Prepare 6 large ultracentrifuge tubes by adding $15 \mathrm{ml}$ of $40 \%$ sucrose to the bottom of each tube.

16 Collect the supernatant from the spin and divide evenly between the 6 ultracentrifuge tubes (approximately $22 \mathrm{ml} /$ tube).

17 Spin at $27000 \mathrm{rpm}$ overnight at $4^{\circ} \mathrm{C}$ (SW-27 rotor, or equivalent).

Day 6

18 Discard the supernatant. Resuspend and combine pellets in a total of $5 \mathrm{ml}$ of $\mathrm{CsCl}$ solution. Use a Pasteur pipette to dislodge and break up pellets until no chunks remain; repeated pipetting will be required. Keep tubes on ice during resuspension.

19 Transfer resuspension solution to a heat-seal tube and fill with additional $\mathrm{CsCl}$ if needed. Seal tube and spin at $50000 \mathrm{rpm}$ overnight at $4{ }^{\circ} \mathrm{C}$ (VTi65 rotor or equivalent).

\section{Day 7}

20 Use razor blade to carefully remove top of heat seal tube. Use a pipette to remove $1 \mathrm{ml}$ fractions, starting from the top, and place each fraction in a $1.5 \mathrm{ml}$ tube.

21 Remove $1 \mu \mathrm{l}$ from each fraction and add to a separate thin-walled tube containing $1 \mu \mathrm{l} 6 \times$ DNA loading buffer and $4 \mu \mathrm{l} \mathrm{H}_{2} \mathrm{O}$. Boil tubes for 3 minutes and place immediately on ice 
22 Run samples in a $1 \%$ agarose gel and stain with ethidium bromide or equivalent dye. Samples from fractions containing viral particles should contain a faint smear of DNA. Only these fractions should be used in the following step.

23 Repeat steps 19-22 using the virus-containing fractions. When adding the fractions to a new heat-seal tube, bring the volume up to $5 \mathrm{ml}$ with additional $\mathrm{CsCl}$ solution.

\section{Day 8}

24 Fill a 2-3 liter bucket with $1.5 \mathrm{~L} 1 \times$ HBSS. Place a dialysis cassette in the bucket and hydrate for at least 10 minutes.

25 Identify the virus-containing fractions from the second $\mathrm{CsCl}$ spin (as in step 22). Using a 20 gauge needle attached to a $5 \mathrm{ml}$ syringe, load these fractions into the hydrated dialysis cassette according to manufacturer's instructions. Place back in the HBSS-filled bucket and dialyze for $2-4$ hours at $4^{\circ} \mathrm{C}$.

26 Exchange the $1 \times \operatorname{HBSS}$ with fresh $1 \times \operatorname{HBSS}(1.5 \mathrm{~L})$ and dialyze overnight at $4{ }^{\circ} \mathrm{C}$

\section{Day 9}

27 Carefully remove solution from dialysis cassette using a syringe and needle, and filter using a $0.2 \mu \mathrm{m}$ pore syringe filter into a $15 \mathrm{ml}$ conical tube.

28 Load a large ultracentrifuge tube with $15 \mathrm{ml} 40 \%$ sucrose. Add the filtered virus solution on top, and fill the remaining volume with $1 \times$ HBSS. Spin at $27000 \mathrm{rpm}$ overnight at $4^{\circ} \mathrm{C}$ (SW-27 rotor, or equivalent).

\section{Day 10}

29 Carefully decant off and discard supernatant. Place tube on ice.

30 Resuspend pellet in $100 \mu \mathrm{l} 1 \times \mathrm{HBSS}$ : add HBSS to tube, cover with parafilm, and vortex. Let sit for 5-10 minutes on ice, then vortex again. Repeat several times until pellet is resuspended. Transfer to $1.5 \mathrm{ml}$ tube. This is your viral suspension.

31 To harvest any residual particles, repeat previous step using a second $100 \mu \mathrm{l}$ of $1 \times$ HBSS. Transfer to a separate $1.5 \mathrm{ml}$ tube labeled "wash".

32 Approximate the titer of the resuspended virus and the wash by running a DNA gel as described in steps 21-22. Compare to viruses of known titer. If viral particles are abundant, dilute the resuspended virus with the wash solution. Further dilution should be done with $1 \times$ HBSS.

$33 \quad$ Aliquot virus and store at $-80^{\circ} \mathrm{C}$.

\section{SUPPORT PROTOCOL 3}

\section{Production of CAV2-Cre}

CAV2-Cre allows for the retrograde transduction and expression of Cre recombinase (Hnasko et al., 2006). Expression of Cre is stable and no adverse effects on cell viability 
following long-term transduction have been reported (Hnasko et al., 2006). Detailed descriptions of the initial cloning and production of CAV2 viral vectors can be found elsewhere (Kremer et al., 2000). Here we will describe the basic method of CAV2-Cre amplification and purification. CAV2-Cre is replication incompetent due to the lack of a critical E1 gene from the viral genome (E1-deleted viral vector) (Kremer et al., 2000). The vector can be amplified using dog kidney (DK) cells with stable expression of the E1 gene (DK-ZEO).

\section{Materials}

DK-ZEO cells

$10 \mathrm{~cm}$ tissue culture dish

$15 \mathrm{~cm}$ tissue culture dish

DK-ZEO culture media (see recipe)

$0.25 \%$ Trypsin-EDTA

CAV2-Cre viral vector stock

Cell scraper

$50 \mathrm{ml}$ conical tubes

Dry ice

$95 \%$ ethanol

$\mathrm{CsCl}$ solutions (see recipes)

Pasteur pipettes

$25 \times 89 \mathrm{~mm}$ large ultracentrifuge tubes (e.g. from Beckman)

$5 \mathrm{ml}$ syringe and 20 guage needle

$14 \times 89 \mathrm{~mm}$ small ultracentrifuge tubes (e.g. from Beckman)

PD-10 Columns (e.g. from GE Life Sciences)

PBS w/ $\mathrm{CaCl}_{2}$ and $\mathrm{MgCl}_{2}$ (see recipe)

$1.5 \mathrm{ml}$ tubes

Viral lysis solution (see recipe)

Water bath $\left(37^{\circ} \mathrm{C}, 56^{\circ} \mathrm{C}\right)$

Incubator for cell culture $\left(37^{\circ} \mathrm{C}, 5 \% \mathrm{CO}_{2}\right)$

Biosafety cabinet

Clinical centrifuge

Ultracentrifuge

SW-27 rotor (or equivalent) 
SW-41 rotor (or equivalent)

Spectrophotometer

\section{Preparation of DK-ZEO cells ( 2 weeks)}

1 Thaw frozen cell stock $\left(\sim 5 \times 10^{6}\right.$ cells $)$ at $37^{\circ} \mathrm{C}$ for approximately 5 minutes. Add to a $10 \mathrm{~cm}$ culture dish along with $10 \mathrm{ml}$ culture media and place in incubator.

2 The next day, aspirate media from plate and immediately add $5 \mathrm{ml}$ TrypsinEDTA. Incubate $5-10$ minutes at $37^{\circ} \mathrm{C}$.

3 Aspirate Trypsin and immediately add $10 \mathrm{ml}$ of culture media to the plate. Triturate cells until dispersed and transfer to a $15 \mathrm{~cm}$ culture dish with an additional $10 \mathrm{ml}$ of culture media. Rock gently to disperse and place in incubator.

4 Grow cells in incubator 2-4 days until confluent. Propagate cells until you have forty $15 \mathrm{~cm}$ dishes of DK-ZEO cells at $~ 70-80 \%$ confluence. Recommended propagation procedure: Split original $15 \mathrm{~cm}$ dish of cells to four $15 \mathrm{~cm}$ dishes, then when confluent split four $15 \mathrm{~cm}$ dishes into ten $15 \mathrm{~cm}$ dishes, and then ten $15 \mathrm{~cm}$ dishes into forty $15 \mathrm{~cm}$ dishes.

Day 1: Viral transduction of DK-ZEO cells and viral amplification: To effectively transduce DK-ZEO cells requires 50-100 viral particles per cell. Each $15 \mathrm{~cm}$ dish will contain $\sim 7.7 \times 10^{7}$ cells, requiring a total of $\sim 3.85-7.7 \times 10^{9}$ viral particles.

5 Add viral particles to $520 \mathrm{ml}$ of culture media and mix gently

6 Aspirate culture media from plates of cells that have grown to confluence. Add $13 \mathrm{ml}$ of the culture media plus viral vector mix to each of the forty $15 \mathrm{~cm}$ dishes.

$7 \quad$ Return cultures to $37^{\circ} \mathrm{C}$ incubator at $5 \% \mathrm{CO}_{2}$. Amplification of the E1-deleted CAV2-Cre vector requires approximately 48 hours of incubation.

\section{Day 3: Harvest and purify viral vector}

8 Use a cell scraper to dislodge cells adhered to the plate and transfer media plus cells to a $50 \mathrm{ml}$ conical tube. Distribute media plus cells from all 40 plates between twelve $50 \mathrm{ml}$ conical tubes.

9 Spin cells at $1160 \times \mathrm{g}$ in a clinical centrifuge for 5 minutes. Remove and save 10 $\mathrm{ml}$ of media and aspirate the remaining media from the conical tubes. Resuspend cells in $10 \mathrm{ml}$ of media to yield a final volume of $\sim 14 \mathrm{ml}$ in one $50 \mathrm{ml}$ conical tube.

10 Liberate viral vector through repeated freeze-thaw cycles. Freeze tube completely in a bath of dry ice and ethanol; solution may turn from red to yellow/orange. Place tube into $37^{\circ} \mathrm{C}$ water bath and thaw completely. Repeat for a total of 3-freeze/thaw cycles. 
11 Spin cells, liberated viral vector, and media at $3220 \times \mathrm{g}$ for 10 minutes.

12 Add $10 \mathrm{ml} \mathrm{CsCl}$ (specific density $1.25 \mathrm{~g} / \mathrm{ml}$ ) to a large ultracentrifuge tube. Carefully add $10 \mathrm{ml} \mathrm{CsCl}$ (specific density $1.40 \mathrm{~g} / \mathrm{ml}$ ) to the bottom of the tube (underneath the $1.25 \mathrm{~g} / \mathrm{ml} \mathrm{CsCl}$ solution) using a Pasteur pipette. Add supernatant from Step 11 to the top by gently pipetting down the side of the tube. Fill remaining volume with PBS. Spin sample for 2 hours and 10 minutes at 27,000 rpm (SW-27 rotor or equivalent).

13 Using a 20-gauge needle attached to a $5 \mathrm{ml}$ syringe, puncture the centrifuge tube just below the viral band (opaque band at the interface of the 1.25 and $1.4 \mathrm{~g} / \mathrm{ml}$ $\mathrm{CsCl}$ solutions). Pull the band by directing the beveled edge of needle just below the bottom of the band. You should get $\sim 2 \mathrm{ml}$ of solution containing the viral band.

14 Add approximately $10 \mathrm{ml} \mathrm{CsCl}$ (specific density $1.34 \mathrm{~g} / \mathrm{ml}$ ) to a small ultracentrifuge tube. Carefully add viral vector from Step 13 to the top by gently pipetting down the side of the tube. Spin sample for 18 hours at 35,000 rpm (SW-41 rotor or equivalent).

Note: the $14 \times 29 \mathrm{ml}$ tube has a volume of $12 \mathrm{ml}$. In order to ensure that your final volume is $12 \mathrm{ml}$, subtract the total volume of viral vector from Step 13 from 12 and add that volume of $\mathrm{CsCl}$ solution to the centrifuge tube.

\section{Day 4}

15 Repeat Step 13.

16 Equilibrate PD-10 column with PBS containing $\mathrm{CaCl}_{2}$ and $\mathrm{MgCl}_{2}$, according to manufacturer's instructions. Label nine $1.5 \mathrm{ml}$ tubes. Add viral vector from Step 15 to the column and collect $1 \mathrm{ml}$ of flow-through into each of the first two tubes. Add $3.5 \mathrm{ml}$ of PBS containing $\mathrm{CaCl}_{2}$ and $\mathrm{MgCl}_{2}$ to the column and collect seven $0.5 \mathrm{ml}$ fractions in the remaining tubes.

17 Dilute $30 \mu \mathrm{l}$ of each fraction with $270 \mu \mathrm{l}$ lysis solution in a fresh tube and incubate in a $56^{\circ} \mathrm{C}$ water bath for 10 minutes. Using a spectrophotometer, measure the $\mathrm{OD}_{260}$ of each fraction and calculate the number of particles using the following formula: $\mathrm{OD}_{260} \times 10 \times 1.1 \times 10^{12}$.

18 Fractions 4-7 typically contain the majority of the CAV2-Cre viral vector. These fractions can be pooled, and aliquoted $\left(20 \mu \mathrm{l}\right.$ each), and stored at $-80^{\circ} \mathrm{C}$. Approximately $500 \mu \mathrm{l}$ should be reserved for subsequent amplifications.

\section{SUPPORT PROTOCOL 4}

\section{Brain sectioning}

Sectioning of brain tissue for post-hoc histology is critical not only for the initial optimization of injection coordinates, but also to ensure consistency among all animals used 
for behavioral or other experiments. Many methods for cutting and mounting of brain sections are available; we present one simple method here.

Note: Immunohistochemistry can be performed as desired on floating sections (following step 9) to stain for a cell-specific marker or other proteins.

Immunohistochemistry is not typically required for visualization of fluorescent reporters such as GFP or TdTomato unless the signal is quite dim.

\section{Materials}

4\% paraformaldehyde (PFA) in PBS, pH 7.4 (see recipe)

Small glass or plastic jar with a secure lid

$30 \%$ sucrose in PBS

Freezing media (e.g. O.C.T. from TissueTek)

Disposable embedding molds

Dry ice

$95 \%$ ethanol

Rounded spatula

$1 \times$ PBS

24- or 48-well plate

Brain atlas

Paintbrush

Glass slides

Mounting media (e.g. Fluoromount)

Cryostat

\section{Protocol Steps}

1. Following perfusion, remove brain from skull and submerge in small jar in $4 \%$ PFA overnight at $4^{\circ} \mathrm{C}$.

2. Decant PFA and replace with $30 \%$ sucrose. Maintain at $4{ }^{\circ} \mathrm{C}$ with gentle rocking or rotation until brain sinks to bottom of container (typically 1-2 days).

3. Fill embedding mold $3 / 4$ full with freezing media. Add brain and use spatula or forceps to orient with olfactory bulbs facing down.

4. Freeze in a shallow bath of dry ice/ethanol, taking care to ensure that brain remains in upright orientation. Ethanol should not come over the top of the cup.

5. Section immediately or store at $-80^{\circ} \mathrm{C}$ indefinitely. If stored at $-80^{\circ} \mathrm{C}$, let equilibrate to $-20^{\circ} \mathrm{C}$ before sectioning. 
6. Peel apart walls of embedding mold to release frozen block. Using additional freezing media, freeze block (olfactory bulbs facing up) to chuck in cryostat.

7. Once block is firmly frozen to cryostat, begin taking $50 \mu \mathrm{m}$ thick sections, referencing the brain atlas to adjust position of brain to ensure even orientation along all 3 axes.

8. Continue taking sections until the region of interest approaches. Take $30 \mu \mathrm{m}$ thick sections through the region of interest, picking up each section with a wet paintbrush and depositing it into one well of a 24- or 48-well plate filled with PBS.

9. If whole brain sectioning is desired, for example to map unknown projection targets, cut $30 \mu \mathrm{m}$ sections through the entire brain, collecting approximately every $3^{\text {rd }}$ slice.

10. Using a paintbrush, mount the slices onto glass slides. Cover with preferred mounting media and a coverslip. Allow to dry completely before imaging.

\title{
REAGENTS AND SOLUTIONS
}

\section{HEK and DK-ZEO culture media}

$500 \mathrm{ml}$ Dulbecco's modified Eagle's medium (DMEM)

$50 \mathrm{ml}$ Fetal Bovine Serum (FBS) for HEK and $10 \mathrm{ml}$ for DK-ZEO

$5 \mathrm{ml} 200 \mathrm{mM}$ L-Glutamine

$5 \mathrm{ml} 100 \times$ Penicillin/Streptomycin

Add FBS, Glutamine, and Pen/Strep to DMEM bottle under sterile conditions. Invert to mix.

\section{Serum-free HEK culture media}

As above, but without the fetal bovine serum.

\section{HEPES solution}

$8.18 \mathrm{~g} \mathrm{NaCl}$

$5.96 \mathrm{~g}$ HEPES

$\mathrm{ddH}_{2} \mathrm{O}$ to $500 \mathrm{ml}, \mathrm{pH}$ to 7.05

Mix until dissolved. Filter sterilize.

\section{Phosphate Mix}

\author{
$4.95 \mathrm{ml} 1 \mathrm{M} \mathrm{NaH}_{2} \mathrm{PO}_{4}$ \\ $10.05 \mathrm{ml} 1 \mathrm{M} \mathrm{Na}_{2} \mathrm{HPO}_{4}$ \\ $85 \mathrm{ml} \mathrm{ddH} 2 \mathrm{O}$
}

Mix until dissolved. Filter sterilize. $1 \mathrm{M}$ stock solutions of phosphates may need to be heated in order to dissolve. 


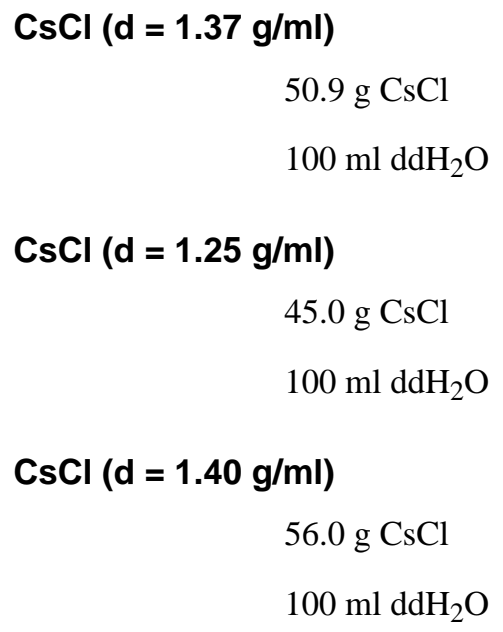

In a graduated cylinder, add $\mathrm{CsCl}$ and top off with water to the exact volume (mix to dissolve). Weigh $1 \mathrm{ml}$ of solution and titrate with water or $\mathrm{CsCl}$ until density is equal to $1.37,1.25$, or 1.40 .

\title{
Viral lysis solution
}

\author{
$0.1 \%$ SDS \\ $10 \mathrm{mM}$ Tris-HCl, $\mathrm{pH} 7.4$
}

\section{4\% Paraformaldehyde (PFA), pH 7.4}

\author{
4 g paraformaldehyde \\ $100 \mathrm{ml}$ PBS \\ 2 pellets $\mathrm{NaOH}$ \\ $\mathrm{HCl}$
}

Combine paraformaldehyde, water, and $\mathrm{NaOH}$. Stir over gentle heat to dissolve. Adjust $\mathrm{pH}$ to 7.4 using $\mathrm{HCl}$.

\section{COMMENTARY}

\section{Background Information}

The diversity of circuit function in the mammalian brain requires approaches enabling the genetic dissection of neuronal function based upon their anatomical connectivity. Brain structures that were once thought to be highly homogenous are now being found to exhibit incredible heterogeneity, both at the genetic and anatomical level. Therefore, it is critical to develop techniques to advance the genetic dissection of complex brain circuits. The protocol outlined here allows for the selective expression of genetic tools to explore subsets of neurons.

The fundamental basis of dual viral approaches is based upon the groundbreaking discovery and development of the Cre-LoxP system for homologous recombination (Sternberg and Hamilton, 1981; Sternberg et al., 1981a; Sternberg et al., 1981b), along with the use of 
single viral vectors to express genes of interest in the central nervous system (Slack and Miller, 1996). Combining these techniques enables the use of one Cre-expressing virus to activate another Cre-dependent virus, which is widely applicable to the selective expression of recombinant genetic tools to study gene-circuit interactions. For example, dual viral expression allows for the precise expression of genetically-encoded calcium indicators, voltage sensors, $\mathrm{pH}$ sensors, and recombinant proteins, both wild type and dominant negative versions.

These technical advances in viral vector development are paralleled by our increasing knowledge of the complex genetic and anatomical connectivity of the brain. First performed solely by individual investigators, the large-scale initiatives at the AIBS and GENSAT provide broadly useful resources for the neuroscience community. These brain atlas projects detail the gene expression profile of all known protein-encoding genes in the mouse genome, along with large numbers of genes for other species including humans and nonhuman primates (Bernard et al., 2012; Hawrylycz et al., 2012; Lein et al., 2007; Zeng et al., 2012). A complementary dataset, also being completed at the AIBS, is a mouse brain connectivity atlas mapping all the interconnections within the brain. Taking advantage of these genetic and anatomical projects, together with the viral approaches in this protocol, will lead to greater insight into the genetic basis of the development and function of the brain.

\section{Critical Parameters and Troubleshooting}

Combinatorial viral approaches require virus to be delivered to multiple locations, and mistargeting to one brain region can negate even perfect targeting to a second region. Therefore, it is important to firmly establish the accuracy and precision of the injection coordinates. Subtle discrepancies between atlas coordinates and the actual results can occur, so optimization is required for each set of injection coordinates. Furthermore, differences can also occur due to the age, sex, and the specific inbred strain used for the experiments.

\section{Anticipated Results}

The ideal result would be targeting $100 \%$ of the neurons that project from one brain region to another. However, as discussed, there are many factors that prevent the realization of this ideal. We have found that we can reproducibly transduce $\sim 90 \%$ of the neurons in a single brain region. If a second brain region can also be targeted with $~ 90 \%$ efficiency, then the theoretical limit on viral co-expression is $\sim 81 \%(90 \% \times 90 \%)$. For certain applications, this amount of transduction efficiency may be sufficient to observe an effect. However, loss of function may require greater levels of inactivation to observe a phenotype. Greater coverage can be achieved by increasing the number of injection sites, but this can lead to incorporation of targeted regions outside the area of interest.

\section{Time Considerations}

The initial mapping experiments to validate each injection coordinate can take from several weeks to several months, depending upon the number of rounds required to produce a high level of targeting accuracy and precision. For example, if using an AAV with a strong promoter (i.e. chicken $\beta$-actin or CMV), strong viral expression of a fluorescent marker can 
be observed after 10 days. Therefore, considering the time to perfuse and possibly stain for marker expression, it will typically take 2-3 weeks to test for expression. If targeting is not correct or if there is a high degree of variability in viral transduction, additional rounds of viral targeting must take place to optimize the coordinates.

Upon completing optimization procedures, combinatorial viral injections can be performed. Depending upon the constructs and application, viral expression can be observed in as little as 10 days. However, for studying functional circuitry, it may be advantageous to wait longer, 2-3 weeks, for maximal viral expression to occur.

\section{Acknowledgments}

We thank members of the Zweifel lab for thoughtful comments and discussion relating to this protocol.

\section{LITERATURE CITED}

Ahmed BY, Chakravarthy S, Eggers R, Hermens WT, Zhang JY, Niclou SP, Levelt C, Sablitzky F, Anderson PN, Lieberman AR, Verhaagen J. Efficient delivery of Cre-recombinase to neurons in vivo and stable transduction of neurons using adeno-associated and lentiviral vectors. BMC neuroscience. 2004; 5:4. [PubMed: 15005815]

Armbruster BN, Li X, Pausch MH, Herlitze S, Roth BL. Evolving the lock to fit the key to create a family of $\mathrm{G}$ protein-coupled receptors potently activated by an inert ligand. Proceedings of the National Academy of Sciences of the United States of America. 2007; 104:5163-5168. [PubMed: 17360345]

Bernard A, Lubbers LS, Tanis KQ, Luo R, Podtelezhnikov AA, Finney EM, McWhorter MM, Serikawa K, Lemon T, Morgan R, Copeland C, Smith K, Cullen V, Davis-Turak J, Lee CK, Sunkin SM, Loboda AP, Levine DM, Stone DJ, Hawrylycz MJ, Roberts CJ, Jones AR, Geschwind DH, Lein ES. Transcriptional architecture of the primate neocortex. Neuron. 2012; 73:1083-1099. [PubMed: 22445337]

Card JP, Kobiler O, Ludmir EB, Desai V, Sved AF, Enquist LW. A dual infection pseudorabies virus conditional reporter approach to identify projections to collateralized neurons in complex neural circuits. PloS one. 2011; 6:e21141. [PubMed: 21698154]

Consortium IHGS. Finishing the euchromatic sequence of the human genome. Nature. 2004; 431:931945. [PubMed: 15496913]

Coward P, Wada HG, Falk MS, Chan SD, Meng F, Akil H, Conklin BR. Controlling signaling with a specifically designed Gi-coupled receptor. Proceedings of the National Academy of Sciences of the United States of America. 1998; 95:352-357. [PubMed: 9419379]

Dong, HW. Allen reference atlas: a digital color brain atlas of the C57Black/6J male mouse. Hoboken, NJ: Wiley; 2008.

Fenno L, Yizhar O, Deisseroth K. The development and application of optogenetics. Annual review of neuroscience. 2011; 34:389-412.

Gregorevic P, Blankinship MJ, Allen JM, Crawford RW, Meuse L, Miller DG, Russell DW, Chamberlain JS. Systemic delivery of genes to striated muscles using adeno-associated viral vectors. Nature medicine. 2004; 10:828-834.

Hadjieconomou D, Timofeev K, Salecker I. A step-by-step guide to visual circuit assembly in Drosophila. Current opinion in neurobiology. 2011; 21:76-84. [PubMed: 20800474]

Hawrylycz MJ, Lein ES, Guillozet-Bongaarts AL, Shen EH, Ng L, Miller JA, van de Lagemaat LN, Smith KA, Ebbert A, Riley ZL, Abajian C, Beckmann CF, Bernard A, Bertagnolli D, Boe AF, Cartagena PM, Chakravarty MM, Chapin M, Chong J, Dalley RA, Daly BD, Dang C, Datta S, Dee N, Dolbeare TA, Faber V, Feng D, Fowler DR, Goldy J, Gregor BW, Haradon Z, Haynor DR, Hohmann JG, Horvath S, Howard RE, Jeromin A, Jochim JM, Kinnunen M, Lau C, Lazarz ET, Lee C, Lemon TA, Li L, Li Y, Morris JA, Overly CC, Parker PD, Parry SE, Reding M, Royall JJ, Schulkin J, Sequeira PA, Slaughterbeck CR, Smith SC, Sodt AJ, Sunkin SM, Swanson BE, 
Vawter MP, Williams D, Wohnoutka P, Zielke HR, Geschwind DH, Hof PR, Smith SM, Koch C, Grant SG, Jones AR. An anatomically comprehensive atlas of the adult human brain transcriptome. Nature. 2012; 489:391-399. [PubMed: 22996553]

Hnasko TS, Perez FA, Scouras AD, Stoll EA, Gale SD, Luquet S, Phillips PE, Kremer EJ, Palmiter RD. Cre recombinase-mediated restoration of nigrostriatal dopamine in dopamine-deficient mice reverses hypophagia and bradykinesia. Proceedings of the National Academy of Sciences of the United States of America. 2006; 103:8858-8863. [PubMed: 16723393]

Hubel DH. The brain. Scientific American. 1979; 241:44-53. [PubMed: 493920]

Judge LM, Chamberlain JS. Gene therapy for Duchenne muscular dystrophy: AAV leads the way. Acta myologica: myopathies and cardiomyopathies: official journal of the Mediterranean Society of Myology / edited by the Gaetano Conte Academy for the study of striated muscle diseases. 2005; 24:184-193.

Kremer EJ, Boutin S, Chillon M, Danos O. Canine adenovirus vectors: an alternative for adenovirusmediated gene transfer. Journal of virology. 2000; 74:505-512. [PubMed: 10590140]

Lammel S, Lim BK, Malenka RC. Reward and aversion in a heterogeneous midbrain dopamine system. Neuropharmacology. 2013

Lein ES, Hawrylycz MJ, Ao N, Ayres M, Bensinger A, Bernard A, Boe AF, Boguski MS, Brockway KS, Byrnes EJ, Chen L, Chen TM, Chin MC, Chong J, Crook BE, Czaplinska A, Dang CN, Datta S, Dee NR, Desaki AL, Desta T, Diep E, Dolbeare TA, Donelan MJ, Dong HW, Dougherty JG, Duncan BJ, Ebbert AJ, Eichele G, Estin LK, Faber C, Facer BA, Fields R, Fischer SR, Fliss TP, Frensley C, Gates SN, Glattfelder KJ, Halverson KR, Hart MR, Hohmann JG, Howell MP, Jeung DP, Johnson RA, Karr PT, Kawal R, Kidney JM, Knapik RH, Kuan CL, Lake JH, Laramee AR, Larsen KD, Lau C, Lemon TA, Liang AJ, Liu Y, Luong LT, Michaels J, Morgan JJ, Morgan RJ, Mortrud MT, Mosqueda NF, Ng LL, Ng R, Orta GJ, Overly CC, Pak TH, Parry SE, Pathak SD, Pearson OC, Puchalski RB, Riley ZL, Rockett HR, Rowland SA, Royall JJ, Ruiz MJ, Sarno NR, Schaffnit K, Shapovalova NV, Sivisay T, Slaughterbeck CR, Smith SC, Smith KA, Smith BI, Sodt AJ, Stewart NN, Stumpf KR, Sunkin SM, Sutram M, Tam A, Teemer CD, Thaller C, Thompson CL, Varnam LR, Visel A, Whitlock RM, Wohnoutka PE, Wolkey CK, Wong VY, Wood M, Yaylaoglu MB, Young RC, Youngstrom BL, Yuan XF, Zhang B, Zwingman TA, Jones AR. Genome-wide atlas of gene expression in the adult mouse brain. Nature. 2007; 445:168-176. [PubMed: 17151600]

Lent R, Azevedo FA, Andrade-Moraes CH, Pinto AV. How many neurons do you have? Some dogmas of quantitative neuroscience under revision. The European journal of neuroscience. 2012; 35:1-9. [PubMed: 22151227]

Lo L, Anderson DJ. A Cre-dependent, anterograde transsynaptic viral tracer for mapping output pathways of genetically marked neurons. Neuron. 2011; 72:938-950. [PubMed: 22196330]

Luo L, Callaway EM, Svoboda K. Genetic dissection of neural circuits. Neuron. 2008; 57:634-660. [PubMed: 18341986]

Madisen L, Zwingman TA, Sunkin SM, Oh SW, Zariwala HA, Gu H, Ng LL, Palmiter RD, Hawrylycz MJ, Jones AR, Lein ES, Zeng H. A robust and high-throughput Cre reporting and characterization system for the whole mouse brain. Nature neuroscience. 2010; 13:133-140.

Osakada F, Mori T, Cetin AH, Marshel JH, Virgen B, Callaway EM. New rabies virus variants for monitoring and manipulating activity and gene expression in defined neural circuits. Neuron. 2011; 71:617-631. [PubMed: 21867879]

Parker JG, Beutler LR, Palmiter RD. The contribution of NMDA receptor signaling in the corticobasal ganglia reward network to appetitive Pavlovian learning. The Journal of neuroscience: the official journal of the Society for Neuroscience. 2011; 31:11362-11369. [PubMed: 21813695]

Paxinos, G.; Franklin, KBJ. The mouse brain in stereotaxic coordinates. 4th ed.. San Diego: Elsevier Academic Press; 2013.

Robles E, Baier H. Assembly of synaptic laminae by axon guidance molecules. Current opinion in neurobiology. 2012; 22:799-804. [PubMed: 22632825]

Scammell TE, Arrigoni E, Thompson MA, Ronan PJ, Saper CB, Greene RW. Focal deletion of the adenosine A1 receptor in adult mice using an adeno-associated viral vector. The Journal of neuroscience: the official journal of the Society for Neuroscience. 2003; 23:5762-5770. [PubMed: 12843280] 
Schnutgen F, Doerflinger N, Calleja C, Wendling O, Chambon P, Ghyselinck NB. A directional strategy for monitoring Cre-mediated recombination at the cellular level in the mouse. Nature biotechnology. 2003; 21:562-565.

Slack RS, Miller FD. Viral vectors for modulating gene expression in neurons. Current opinion in neurobiology. 1996; 6:576-583. [PubMed: 8937820]

Soudais C, Laplace-Builhe C, Kissa K, Kremer EJ. Preferential transduction of neurons by canine adenovirus vectors and their efficient retrograde transport in vivo. FASEB journal: official publication of the Federation of American Societies for Experimental Biology. 2001; 15:22832285. [PubMed: 11511531]

Sternberg N, Hamilton D. Bacteriophage P1 site-specific recombinationI. Recombination between loxP sites. Journal of molecular biology. 1981; 150:467-486. [PubMed: 6276557]

Sternberg N, Hamilton D, Austin S, Yarmolinsky M, Hoess R. Site-specific recombination and its role in the life cycle of bacteriophage P1. Cold Spring Harbor symposia on quantitative biology. 1981a; 45(Pt 1):297-309.

Sternberg N, Hamilton D, Hoess R. Bacteriophage P1 site-specific recombination. II. Recombination between loxP and the bacterial chromosome. Journal of molecular biology. 1981b; 150:487-507. [PubMed: 6276558]

Wang Z, Jin Y. Genetic dissection of axon regeneration. Current opinion in neurobiology. 2011; 21:189-196. [PubMed: 20832288]

Witten IB, Steinberg EE, Lee SY, Davidson TJ, Zalocusky KA, Brodsky M, Yizhar O, Cho SL, Gong S, Ramakrishnan C, Stuber GD, Tye KM, Janak PH, Deisseroth K. Recombinase-driver rat lines: tools, techniques, and optogenetic application to dopamine-mediated reinforcement. Neuron. 2011; 72:721-733. [PubMed: 22153370]

Zeng H, Shen EH, Hohmann JG, Oh SW, Bernard A, Royall JJ, Glattfelder KJ, Sunkin SM, Morris JA, Guillozet-Bongaarts AL, Smith KA, Ebbert AJ, Swanson B, Kuan L, Page DT, Overly CC, Lein ES, Hawrylycz MJ, Hof PR, Hyde TM, Kleinman JE, Jones AR. Large-scale cellular-resolution gene profiling in human neocortex reveals species-specific molecular signatures. Cell. 2012; 149:483-496. [PubMed: 22500809] 
A

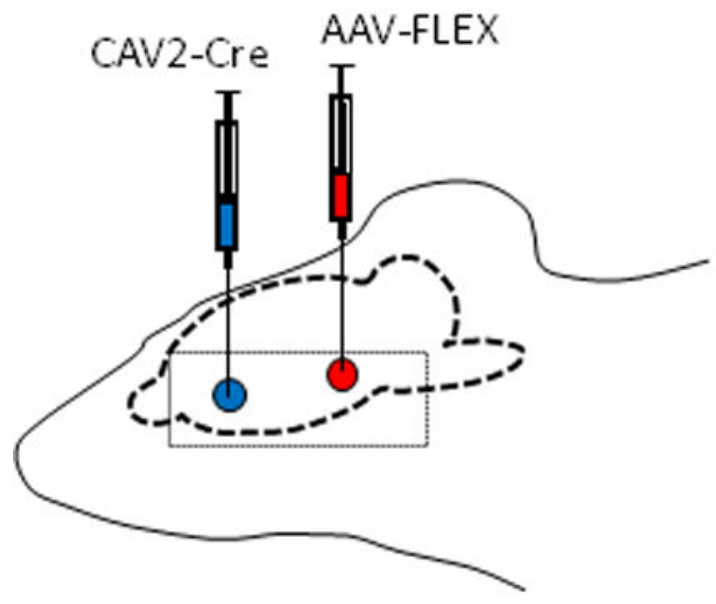

B

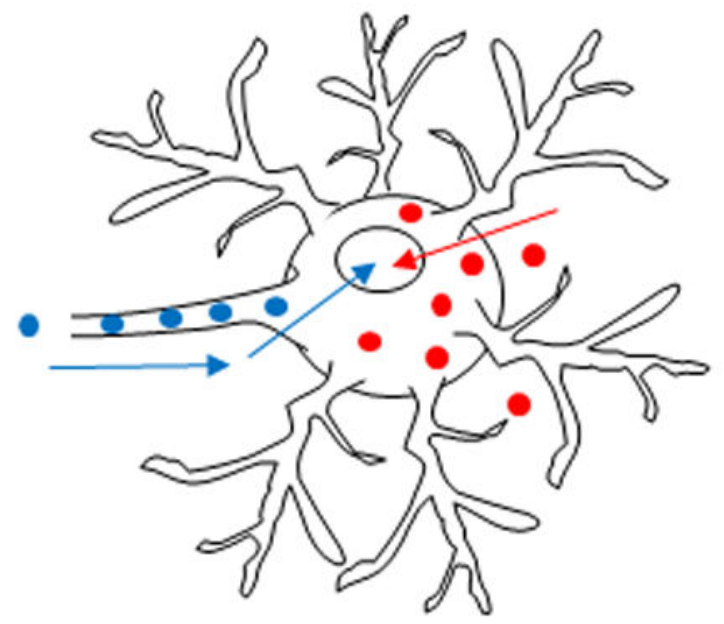

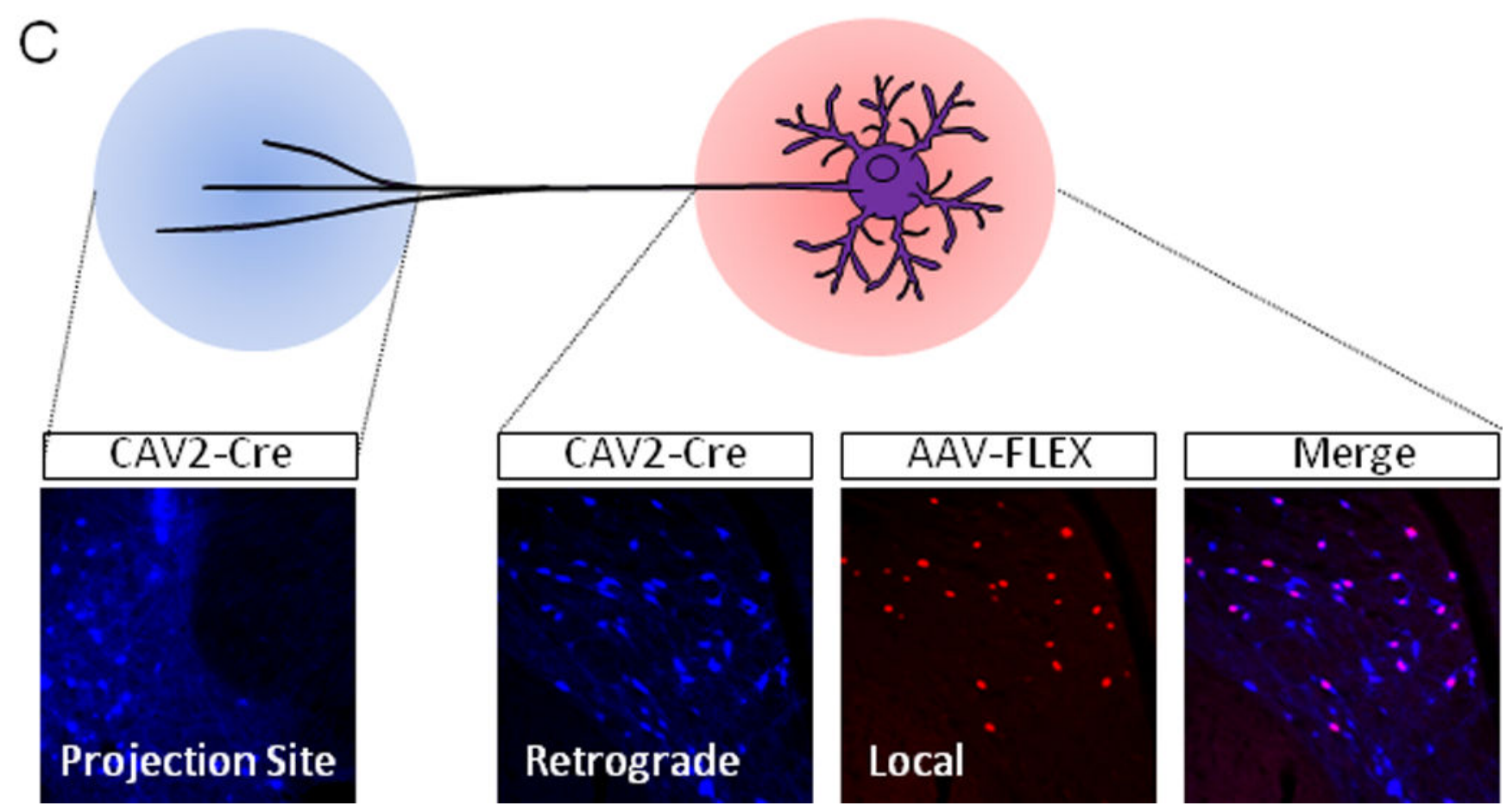

Figure 1.

Combinatorial viral delivery to study pathway specific gene function. (A) Illustration of combined viral injections of a conditional AAV-FLEX construct (red) into a region containing a neuronal population of interest and a CAV2-Cre viral vector (blue) into a projection target of the neurons of interest. (B) Illustration of local (red) AAV-FLEX viral vector transduction and retrograde (blue) CAV2-Cre transduction. (C) Demonstration of combinatorial viral-mediated gene expression. Injection of CAV2-Cre into a target region of interest (blue) of a Cre-dependent reporter line (Ai14) illustrates coverage area of viral vector injection and the number of neurons retrogradely transduced. Injection of AAVFLEX containing conditional expression cassette of interest locally transduces neurons at the 
sight of injection; however, only neurons with combined CAV2-Cre and AAV-FLEX will express the transgene (red). 


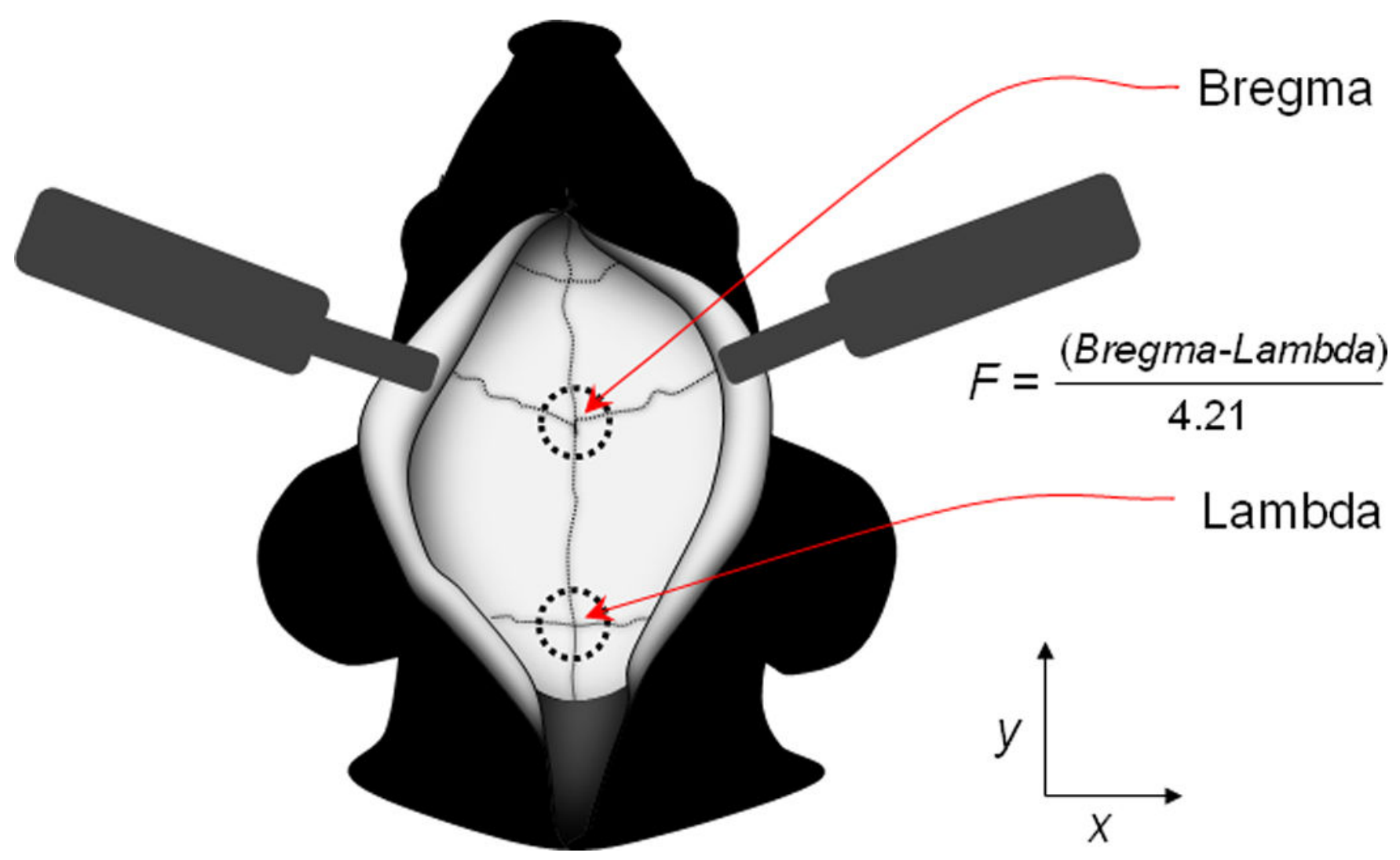

Figure 2.

Illustration demonstrating the identification of Bregma and Lambda on a mouse skull. Following incision, the scalp is held open using skin clamps, allowing access to the top of the skull. Bregma can be seen as the intersection of the midline rostral-caudal fissure and the second major medial-lateral fissure. Lambda can be identified as the most rostral mediallateral fissure. Stereotaxicxand y coordinates are set to zero at Bregma. Moving from midline to the left is in the negativexdirection and positive from midline to the right. Similarly, y coordinates are negative caudal to Bregma and positive rostral to Bregma. Stereotaxic targeting of the y coordinate can be improved using a Bregma-Lambda correction factor (F), taken as the distance between Bregma and Lambda and dividing by 4.21 (the distance from Bregma to Lambda in a commonly used mouse brain atlas). 